Volume $3 \cdot$ Nomor $3 \cdot$ Juni 2020

Pege $(\mathrm{Hal}): 59-65$

(C) Universitas Pamulang

JL.Surya Kencana No.1 Pamulang, Tangerang Selatan - Banten

Telp. (021) 7412566, Fax (021) 7412491

website. :

Email : jurnalmarketing.unpam@gmail.com

\title{
Pengaruh Kualitas Produk dan Promosi Terhadap Minat Beli Yang Berdampak Pada Keputusan Pembelian Pada Pelanggan Aprilia Bakery
}

\author{
Rahmad Setiawan \\ Universitas Pamulang, Email : dosen02452@unpam.ac.id
}

\begin{abstract}
Abstrak. Tujuan penelitian mengetahui pengaruh kualits produk, dan promosi terhadap minat beli serta pengaruh minat beli terhadap keputusn pembelian. Metode Asosiatif dipergunakan dalam penelitian ini. Populasi disini pelanggan Aprilia Bakery, sampel sebanyak 100 responden. Pengumpulan data dengan cara menyebarkan angket, dan Teknik analisis data yaitu regresi linier berganda dan regresi linier sederhana. Hasil penelitian menunjukan bahwa: Kualitas prodok berpengaruh positif dan signifikan terhadap minat beli. Promosi berpengaruh positif dan signifikan terhadap minat belli. Kualitas produk dan promosi secara simultan berpengaruh positif dan signifikan terhadap minat beli. Minat beli berpengaruh positif dan signifikan terhadap keputusan pembelian.
\end{abstract}

Kata Kunci: Kualitas Produk; Promosi; Minat Beli; Keputusan Pembelian.

Abstract. The research objective is to determine the effect of product quality, and promotion of buying interest and the effect of buying interest on purchasing decisions. The associative method was used in this study. The population here is Aprilia Bakery customers, a sample of 100 respondents. Data collection by distributing questionnaires, and data analysis techniques are multiple linear regression and simple linear regression. The results showed that: Product quality has a positive and significant effect on buying interest. Promotion has a positive and significant effect on buying interest. Product quality and promotion simultaneously have a positive and significant effect on buying interest. Buying interest has a positive and significant effect on purchasing decisions.

Keywords: Product Quality; Promotion; Purchase Interests and Purchasing Decisions.

\section{A. PENDAHULUAN}

Aprilia Bakery adalah salah satu perusahaan roti UMKM. Roti adalah makanan praktis dan sehat yang dapat dinikmati di mana saja dan kapan saja dan oleh siapa saja. Didirikan pada tahun 1996, Aprilia Bakery sekarang memiliki kantor di Ciledug Tangerang. Aprilia Bakery diproduksi untuk memfasilitasi kebiasaan makan sehat dan gaya hidup yang semakin padat yang terjadi di masyarakat. Untuk memperkuat posisinya sebagai konsumen yang aman akan produk roti, Aprilia Bakery selalu menghasilkan produk yang berkualitas tinggi, sehat, halal, dan aman untuk dikonsumsi. Banyak variasi rasa yang ditawarkan kepada pelanggan dengan berbagai aneka rasa yang tentunya sangat lezat dan nikmat. Namun dalam perjalanan usahanya serta banyaknya pesaing sejenis membuat Aprilia 
Bakery mengalami permasalahan pada keputusan pembelian yang tiap tahun mengalami penurunan.

Tabel 1. Data Penjualan Aprilia Bakery

\begin{tabular}{|c|c|c|c|}
\hline Tahun & Penjualan (Rp) & Perkembangan (Rp) & $\%$ \\
\hline 2013 & 750.000 .000 & - & - \\
\hline 2014 & 810.000 .000 & 60.000 .000 & $7 \%$ \\
\hline 2015 & 825.000 .000 & 15.000 .000 & $2 \%$ \\
\hline 2016 & 800.000 .000 & -25.000 .000 & $-3 \%$ \\
\hline 2017 & 792.000 .000 & -8.000 .000 & $-1 \%$ \\
\hline
\end{tabular}

Sumber: Aprilia Bakery

Tabel 1 tersebut menunjukkan penjualan Roti pada Aprilia Bakery selama lima tahun mengalami fluktuatif. Namun pada tahun 2016 penjualan menurun sebesar -3\% serta tahun 2017 juga mengalami penurunan sebesar $-1 \%$ bila dibandingkan penjualan sebelumnya. Penjualan yang menurun selama dua tahun pada Aprilia Bakery disebabkan banyak faktor salah satunya adalah bersaing dengan pengusaha roti lokal yang mengembangkan tokotoko modern yang melakukan proses produksi roti untuk dijual sendiri seperti Sari Roti, Majestik dan Papa \& Mama Bakery serta pesaing asing seperti Breadtalk, J.Co, Breadlife, Holand Bakery dan sebagainya.

Kotler dan Amstrong (2012:78), mendefinisikan "kualitas produk merupakan salah satu senjata strategis yang potensial untuk mengalahkan pesaing, jadi hanya perusahaan dengan kualitas produk paling baik yang akan tumbuh dengan pesat, dan dalam jangka waktu yang panjang perusahaan tersebut akan lebih berhasil dari perusahaan yang lain". Keunggulan-keunggulan dari suatu barang atau produk yang dihasilkan oleh peruahaan dapat diketahui oleh konsumen dan akan menimbulkan suatu kesadaran akan merek produk tersebut. Kualitas produk yang unggul baik dari rasa yang ditwarkan, variasi kemasan yang menarik akan dapat memberikan minat kepada pelanggan yang tentunya akan melakukan suatu proses pembelian.

Promosi adalah salah satu variabel kompleks pemasaran yang menentukan keberhasilan program pemasaran. Terkadang istilah promosi digunakan secara sinonim dengan istilah penjualan, meskipun itu dimaksudkan untuk promosi. Bahkan, istilah penjualan hanya mengacu pada penghapusan barang atau jasa atau penggunaan penjual, dan tidak ada iklan atau kegiatan lain yang bertujuan mendorong permintaan. Jadi menjual hanyalah bagian dari promosi. Djaslim (2010:123), menyatakan "promosi adalah komunikasi informasi antara penjual dan pembeli yang tujuan untuk merubah sikap dan tingkah laku pembeli, yang tadinya tidak mengenal menjadi mengenal sehingga menjadi pembeli dan tetap mengenal produk itu". Dengan adanya promosi yang baik akan membuat suatu produk dapat dikenal luas oleh pelanggan, hal ini tentu saja akan merangsang suatu keinginan dari pelanggan untuk mencoba membeli produk yang ditawarkan.

\section{B. KAJIAN LITERATUR}

\section{Kualitas Produk}

Menurut Fandy (2014:299), "kualitas produk sebagai tingkat mutu yang diharapkan dan pengendalian keragaman dalam mencapai mutu tersebut untuk memenuhi kebutuhan konsumen". Adapun Kotler \& Gary (2012:354), "kualitas produk adalah kemampuan suatu produk untuk melaksanakan fungsinya, meliputi daya tahan, kehandalan, kemudahan operasi dan perbaikan, serta atribut nilai". 


\section{Promosi}

Djaslim (2010:123), "promosi adalah komunikasi informasi antara penjual dan pembeli yang tujuan untuk merubah sikap dan tingkah laku pembeli, yang tadinya tidak mengenal menjadi mengenal sehingga menjadi pembeli dan tetap mengenal produk itu". Kotler \& Amstrong (2012:408) mengemukakan bahwa "Promosi adalah suatu alat untuk berkomunikasi pembeli dan perusahaan lain yang bertujuan untuk merubah memberikan informasi secara lugas".

\section{Minat Beli}

Ferdinand (2012:126-127), "minat beli adalah tahap kecenderungan responden untuk bertindak sebelum keputusan membeli benar-benar dilaksanakan". Sedangkan pengertian minat beli menurut Sciffman dan Kanuk (2013:228) adalah: "Suatu model sikap seseorang terhadap objek barang yang sangat cocok dalam mengukur sikap terhadap golongan produk, jasa, atau merek tertentu".

\section{Keputusan Pembelian}

Sofyan (2012:141), "keputusan pembeliann adalah proses pengambilan keputusan pembeliann yang melibatkan menentukan apa yang akan atau tidak akan dibeli, dan keputusn itu berasal dari tindakan masa lalu yang didapat dari pelanggan itu sendiri". Menurut Fandy (2014:20), "keputusan pembelian konsumen merupakan sebuah tindakan yang dilakukan konsumen untuk membeli suatu produk serta dalam proses pengambilan keputusan yang menentukan adalah kegiatan tersebut".

\section{Kerangka Berfikir}

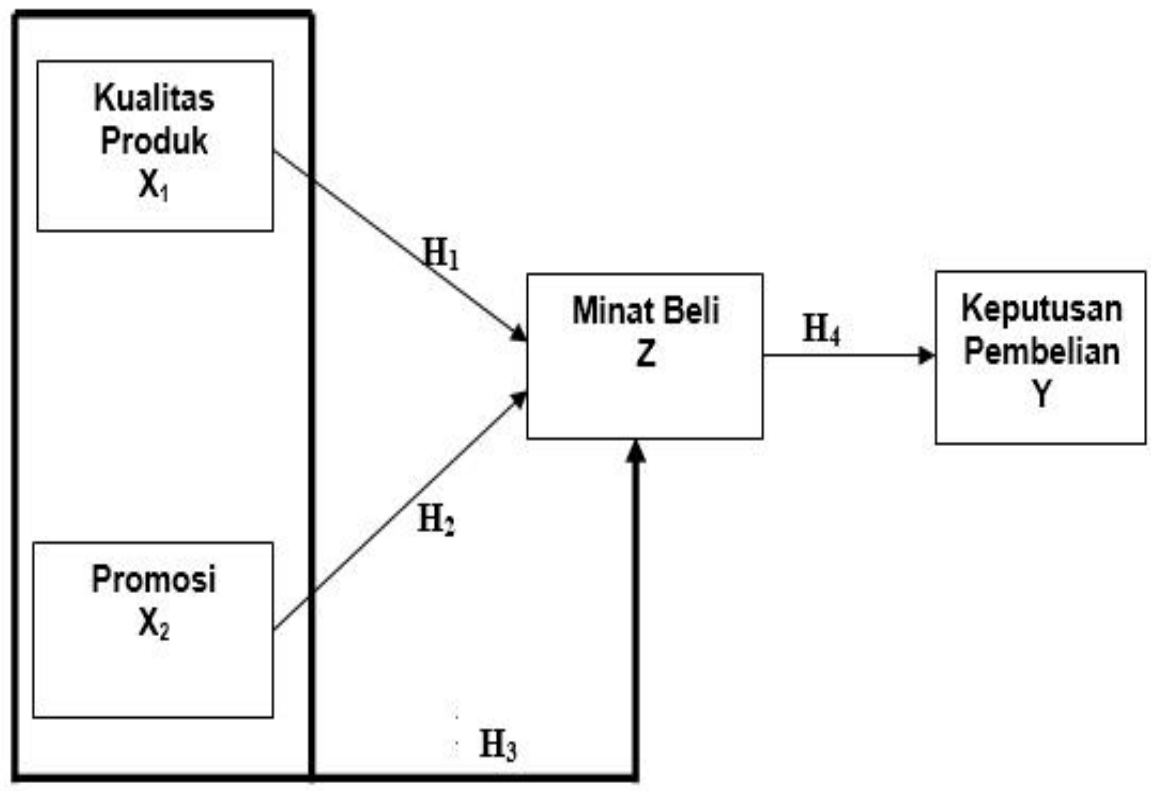

Gambar 1 Kerangka Berfikir 


\section{METODOLOGI PENELITIAN}

Metode penelitian yang digunakan dengan metode Asosiatif, Sugiono (2015:44) berpendapat bahwa "penelitian Asosiatif bertujuan untuk mengetahui pengaruh atau hubungan antara dua variabel lebih". Populasi disini adalah pelanggan Roti Aprilia Bakery. Dalam penelitian ini sampel yang digunakan sebanyak 100 responden. Analisiss data menggunakan Analisiss Regresi Linieer Sederhaana, Liniier Berganda, Korelasi, Koefisieen Determinasi dan uji Hipotesis.

\section{HASIL DAN PEMBAHASAN}

\section{Regresi Linier Berganda}

Tabel 2 Regresi Berganda Kualitas Produk $\left(X_{1}\right)$ dan Promosi $\left(X_{2}\right)$ Terhadap Minat Beli $(Y)$

\begin{tabular}{|c|l|r|r|r|r|r|}
\hline \multicolumn{2}{|c|}{ Model } & \multicolumn{2}{|c|}{$\begin{array}{c}\text { Unstandardized } \\
\text { Coefficients }\end{array}$} & $\begin{array}{c}\text { Standardized } \\
\text { Coefficients }\end{array}$ & \multirow{2}{*}{$t$} & \multirow{2}{*}{ Sig. } \\
\cline { 3 - 6 } & \multicolumn{1}{|c|}{ B } & Std. Error & Beta & & \\
\hline \multirow{2}{*}{1} & (Constant) & 11,901 & 2,388 & & 4,985 & 0,000 \\
\cline { 2 - 6 } & Kualitas produk & 0,660 & 0,099 & 0,539 & 6,661 & 0,000 \\
\cline { 2 - 5 } & Promosi & 0,114 & 0,040 & 0,229 & 2,832 & 0,006 \\
\hline
\end{tabular}

a. Dependent Variable: Minat Beli

Sumber: Hasil Olahan Data SPSS 24

$Y=11,901+0,660 X_{1}+0.114 X_{2}$

1. Nilai contant sebesar 11,901 artinya apabila kualitas produkk dan promosii tidak mengalami peningkatan sama sekali, maka minat beli tetap 11,901.

2. Kualitas produk memperoleh nilai regresi $0,660 \mathrm{X}_{1}$ yang berarti bahwa pengaruh yang searah yang artinya jika tingkat kualitas produk semakin baik dimata pelanggan, baik dari rasa, kemasan, dan atribut lainnya maka akan membuat peningkatan minat beli 0,660 .

3. Promosi memperoleh nilai regresi $0,114 X_{2}$ yang berarti bahwa pengaruh yang searah yang artinya semakin gencar promosi yang dilakukan Aprilia Bakery kepada pelanggan maka akan semakin membuat peningkatan minat beli 0,114.

\section{Regresi Linier Sederhana}

Tabel 3 Regresi Sederhana Minat Beli (Y) Terhadap Keputusan

Pembelian (Z)

\begin{tabular}{|l|l|r|r|r|r|r|}
\hline \multicolumn{2}{|c|}{ Model } & \multicolumn{2}{|c|}{$\begin{array}{c}\text { Unstandardized } \\
\text { Coefficients }\end{array}$} & $\begin{array}{c}\text { Standardized } \\
\text { Coefficients }\end{array}$ & \multirow{2}{*}{ t } & \multirow{2}{*}{ Sig. } \\
\cline { 3 - 5 } \multicolumn{2}{|c|}{} & \multicolumn{1}{|c|}{ B } & Std. Error & Beta & & \\
\hline \multirow{2}{*}{1} & (Constant) & 20,277 & 2,732 & & 7,422 & 0,000 \\
\cline { 2 - 5 } & Minat Beli & 0,593 & 0,087 & 0,567 & 6,812 & 0,000 \\
\hline
\end{tabular}

a. Dependent Variable: Keputusan Pembelian

Sumber: Hasil Olahan Data SPSS 24 
Nilai constant 20,277 artinya apabila minat beli (Y) bernilai nol atau tidak mengalami peningkatan sama sekali, maka keputusan pembeliann (Z) tetap 20,277 . Koefisiien regresi nilai (b) 0,593 (positif) membuktikan adanya pengaruh yang searah hal ini memberikan arti bahwa semakin minat beli pelanggan tinggi terhadap produk-pproduk dari aprilia bakery maka akan semakin membuat peningkatan keputusan pembelian 0,593.

\section{Korelasi}

Sugiyono (2017:185) menyatakan bahwa "pengujian korelasi digunakan untuk mengukur kekuatan hubungan antara variabel independent $(X)$ terhadap variabel dependen (Y), apakah kekuatan hubungan tersebut sangat kuat, kuat, cukup kuat, rendah dan sangat rendah".

Tabel 4 Korelasi

\begin{tabular}{|l|l|r|r|r|r|}
\hline \multicolumn{2}{|c|}{} & $\begin{array}{c}\text { Keputusan } \\
\text { Pembelian }\end{array}$ & $\begin{array}{c}\text { Kualitas } \\
\text { produk }\end{array}$ & Promosi & $\begin{array}{c}\text { Minat } \\
\text { Beli }\end{array}$ \\
\hline \multirow{3}{*}{$\begin{array}{l}\text { Pearson } \\
\text { Correlation }\end{array}$} & Keputusan Pembelian & 1,000 &, 600 &, 401 &, 567 \\
\cline { 2 - 6 } & Kualitas produk &, 600 & 1,000 &, 241 &, 594 \\
\cline { 2 - 6 } & Promosi &, 401 &, 241 & 1,000 &, 359 \\
\cline { 2 - 6 } & Minat Beli &, 567 &, 594 &, 359 & 1,000 \\
\hline \multirow{4}{*}{ Sig. (1-tailed) } & Keputusan Pembelian & &, 000 &, 000 &, 000 \\
\cline { 2 - 6 } & Kualitas produk &, 000 & &, 008 &, 000 \\
\cline { 2 - 6 } & Promosi &, 000 &, 008 & &, 000 \\
\cline { 2 - 6 } & Minat Beli & 1000 &, 000 &, 000 & \\
\hline \multirow{3}{*}{$N$} & Keputusan Pembelian & 100 & 100 & 100 & 100 \\
\cline { 2 - 6 } & Kualitas produk & 100 & 100 & 100 & 100 \\
\cline { 2 - 6 } & Promosi & 100 & 100 & 100 & 100 \\
\cline { 2 - 6 } & Minat Beli & & & & 100 \\
\hline
\end{tabular}

1. Tingkat kekuatan hubungan kualitas produk Aprilia Bakery terhadap minat beli adalah cukup kuat dengan angka $r=0,594$.

2. Tingkat kekuatan hubungan promosi Aprilia Bakery terhadap minat beli adalah rendah dengan angka $r=0,359$.

3. Tingkat kekuatan hubungan minat beli Aprilia Bakery terhadap keputusan pembelian adalah cukup kuat dengan angka $r=0,567$.

\section{Koefisien Determinasi}

Tabel 5 Koefisien Determinasi Kualitas Produk dan Promosi Terhadap Minat Beli

\begin{tabular}{|l|c|r|r|r|}
\hline Model & $\mathrm{R}$ & $\mathrm{R}$ Square & Adjusted R Square & $\begin{array}{c}\text { Std. Error of the } \\
\text { Estimate }\end{array}$ \\
\hline 1 &, $634^{\mathrm{a}}$ & 0,402 & 0,390 & 4,87837 \\
\hline
\end{tabular}

a. Predictors: (Constant), Promosi, Kualitas produk

b. Dependent Variable: Minat Beli

Sumber: Hasil Olahan Data SPSS 24

Rsquare dari 0,402 berarti bahwa 40,2\% dari variabel minat belli dipengaruhi dari variabel kualitas produk dan promosi, sedangkan sisanya $59,8 \%$ diakibatkan adanya faktorfaktor lain yang tidak termasuk kedalam model. 
ISSN NO. (PRINT) 2598-0823, (ONLINE) 2598-2893

Tabel 6 Koefisien Determinasi Minat Beli Terhadap Keputusan

Pembelian

\begin{tabular}{|l|c|r|r|c|}
\hline Model & $\mathrm{R}$ & $\mathrm{R}$ Square & Adjusted R Square & $\begin{array}{c}\text { Std. Error of the } \\
\text { Estimate }\end{array}$ \\
\hline 1 &, $567^{\mathrm{a}}$ & 0,321 & 0,314 & 5,40657 \\
\hline
\end{tabular}

a. Predictors: (Constant), Minat Beli

b. Dependent Variable: Keputusan Pembelian

Sumber: Hasil Olahan Data SPSS 24

Rsquare dari 0,321 atau juga $32,1 \%$ dari variabel keputusan pembelian dipengaruhi dari variabel minat beli, sedangkan sisanya $67,9 \%$ diakibatkan adanya faktor-faktor lain yang tidak termasuk kedalam model.

\section{Uji t Parsial}

1. Berdasarkan hasil pengujian statistik pada tabel 2 angka angka sig $(0,000<0,05)$ menunjukan diterimanya $\mathrm{H} 1$ dan ditolaknya $\mathrm{Ho} 1$ yang berarti bahwa kualitass produkk memiliki pengaruh positf dan signifikn terhadap minatt belli Aprilia Bakery.

2. Berdasarkan hasil pengujian statistik pada tabel 2 angka angka sig $(0,006<0,05)$ menunjukan diterimanya $\mathrm{H} 2$ dan ditolaknya $\mathrm{Ho} 2$ yang berarti bahwa promossi memiliki pengaruh positf dan signifikn terhadap minatt belli Aprilia Bakery.

3. Berdasarkan hasil pengujian statistik pada tabel 3 angka angka sig $(0,000<0,05)$ menunjukan diterimanya $\mathrm{H} 4$ dan ditolaknya $\mathrm{Ho} 4$ yang berarti bahwa minat belli memiliki pengaruh positf dan signifikn terhadap keputsn pembeliann Aprilia Bakery.

\section{Uji F Simultan}

Tabel 7 Uji $\mathbf{F}_{\text {hitung }}$ Kualitas Produk $\left(\mathbf{X}_{1}\right)$ dan Promosi $\left(\mathbf{X}_{2}\right)$ Terhadap Minat Beli (Y)

\begin{tabular}{|l|l|r|r|r|r|c|}
\hline \multicolumn{2}{|c|}{ Model } & $\begin{array}{c}\text { Sum of } \\
\text { Squares }\end{array}$ & df & $\begin{array}{c}\text { Mean } \\
\text { Square }\end{array}$ & F & Sig. \\
\hline \multirow{2}{*}{1} & Regression & 1552,705 & 2 & 776,352 & 32,622 &, $000^{6}$ \\
\cline { 2 - 7 } & Residual & 2308,455 & 97 & 23,799 & & \\
\cline { 2 - 7 } & Total & 3861,160 & 99 & & & \\
\hline
\end{tabular}

a. Dependent Variable: Minat Beli

b. Predictors: (Constant), Promosi, Kualitas produk

Sumber: Hasil Olahan Data SPSS 24

Hasil di atas menunjukkan bahwa angka signifikansi lebih kecil dan lebih rendah dari 0,05 atau $(0,000<0,05)$, serta $F_{\text {hitungg }} 32,622>F_{\text {tabell }} 3,09$ membuat pilihan variabel kualitas produk dan promosi adalah tepat dan cocok untuk menjelaskan variabel minat beli dengan pengaruh positif dan signifikan.

\section{E. KESIMPULAN}

1. Semakin bagus kualitas produk yang ditawarkan kepada pelanggan Aprilia Bakery akan membuat peningkatan minat beli Aprilia Bakery. Pengaruh dari variabel tersebut adalah positif signifikan atau $(0,000<0,05)$. 
2. Semakin gencar promosi yang dilakukan oleh Aprilia Bakery akan membuat peningkatan minat beli Aprilia Bakery. Pengaruh dari variabel tersebut adalah positif signifikan atau $(0,006<0,05)$.

3. Semakin bagus kualitas produk yang ditawarkan kepada pelanggan Aprilia Bakery dan tingginya insensitas promosi yang dilakukan secara serempak akan membuat peningkatan minat beli Aprilia Bakery. Pengaruh dari variabel tersebut adalah positif signifikan atau $(0,000<0,05)$.

4. Tingginya minat pelanggan Aprilia Bakery akan membuat peningkatan keputusan pembelian pada Aprilia Bakery. Pengaruh dari variabel tersebut adalah positif signifikan atau $(0,000<0,05)$.

\section{DAFTAR PUSTAKA}

Darmadi \& Setiawan, R. (2020), "Analisis Implementasi Global Vision Melalui Straregi Pemasaran Perusahaan Roti Maulana Bakery Yang Berimplikasi Pada Daya Saing”, Jurnal Ekonomi Efektif, Vol. 2. No. 2.

Ferdinand, A. (2012), "Manajemen Pemasaran: Sebuah Pendekatan Strategik, Program Magister Manajemen", Semarang: Universitas Diponegoro.

Lesmana, R., \& Ayu, S. D. (2019), "Pengaruh Kualitas Produk Dan Citra Merek Terhadap Keputusan Pembelian Kosmetik Wardah PT Paragon Tehnology And Innovation". Jurnal Pemasaran Kompetitif. Vol. 2. No. 3.

Kotler, P., \& Armstrong, G. (2012). “Prinsip-prinsip Pemasaran”. Edisi 13. Jilid 1. Jakarta: Erlangga.

Saladin, D. (2010), “Manajemen Strategi dan Kebijakan Perusahaan”, Edisi Lima, Bandung: Linda Karya.

Sciffman \& Kanuk, (2013), "Perilaku Konsumen”, Edisi ke 7, Jakarta: PT Indeks.

Sofjan, A. (2012). "Strategic Marketing Sustaining Lifetime Customer Value". Jakarta. Raja Grafindo Persada.

Sugiyono. (2015). “Metode Penelitian Kuantitatif Kualitatif R\&B”. Bandung: Aflabeta.

Tjiptono, F. (2014). "Pemasaran Jasa”. Yogyakarta: Andi. 